\title{
Analysis of Bidirectional Wireless Optical Channel Integrated with Optical Fiber
}

\author{
Pushplata Tiwari \\ Department of \\ ECE,SHIATS-DU \\ Allahabad, India
}

\author{
A.K.Jaiswal \\ Department of ECE, \\ SHIATS-DU \\ Allahabad, India
}

\author{
Neelesh Agrawal \\ Asst. Professor \\ Department of ECE, \\ SHIATS-DU \\ Allahabad, India
}

\author{
Navendu Nitin \\ Asst. Professor \\ Department of ECE, \\ SHIATS-DU \\ Allahabad, India
}

\begin{abstract}
In present scenario the demands of high speed communication is increasing day by day there are so many technique to increase the speed of communication but the most popular technique is free space optical communication also known as optical wireless channel (OWC).OWC is an high speed and large capacity type of communication system.OWC uses infrared light to convey message from transmitter to receiver.OWC is the solution of last mile problem mainly in overpopulated urban areas. On the other hand the optical fiber also plays a very important role in optical communication system due to its very low loss $(0.2 \mathrm{~dB} / \mathrm{km})$, light weight \& high bandwidth. The low cost of cable make it the ideal solution for transporting the radio signals. In this paper it is demonstrated that integration of OWC \& Optical Fiber technology makes system more advanced, cost effective, high BW \& high data rate. The proposed integrated system is simulated on the Optisystem software and the analysis is made on the basis of Q-factor, BER \& power received.
\end{abstract}

\section{Keywords}

OWC, WDM-EPON, Optisystem software. Fiber to ONUs,

\section{INTRODUCTION}

In communication system there are so many ways of communication but the wireless communication is very essential part of communication system. In wireless communication the information can be transferred over a long distance without any need of wire or cable. Optical communication is a type of wireless communication in which no need of such a wire or cable connection. There are two type of optical communication: Optical wireless channel (OWC) communication and Optical Fiber communication.OWC is an ultra high speed \& large capacity communication, uses free space as a channel \& laser light in IR region as a carrier. The laser light has very narrow beam width so it can travel a long distance. The other advantages of OWC are that it uses a very small size of Antenna at Transmitter and Receiver side. The use of OWC also minimizes the power used for communication system and offeres high data rate. Most attractive benefit of OWC is its capability to utilize a large amount of unregulated licensed free bandwidth.OWC solves the problem of "last mile" mainly in overpopulated urban areas. Optical Fiber communication is type of optical communication which uses optical fiber as a communication channel. The traditional link between the receivers to Optical Network Units (ONUs) is copper cable which make deployment of the hardware is very tough. Instead of this the deployment of optical fiber LAN's (local area network) is much easier. It carrying traffic at data rate of tens of Gigabits per second \& offering $\mathrm{THz}$ of bandwidth at very low attenuation $(0.2 \mathrm{~dB} / \mathrm{km})$.In this paper Integration of Optical Wireless Channel and Optical Fiber makes system very useful and attractive. The advantages of both technique combine together and make a new technology which leads the communication in new era.

\section{METHODOLOGY}

\subsection{Optical wireless channel}

Basically radio signal transmission is analog transmission system which is converted in to digital form by using PRBS generator (bit rate $2.5 \mathrm{Gbps}$ ) and NRZ modulation technique (sample rate $160 \mathrm{GHz}$ ).For optical modulation external modulation is used, which is mach-zehnder modulator(M-Z modulator) in which a $\mathrm{CW}$ laser array of four different wavelength of carrier signal (four different wavelength of laser signal) around the wavelength $1550 \mathrm{~nm}$ and frequency spacing $100 \mathrm{GHZ}$ and $5 \mathrm{dBm}$ power are used which is multiplexed by WDM(wavelength division multiplexing) having same frequency and frequency spacing as $\mathrm{CW}$ laser has.MZ modulator has very less dispersive effect. MZ modulator modulates the digitized RF signal with the help of multiplexed laser signal and send through OWC.

\subsection{Ethernet passive optical network Architecture (EPON)}

An EPON consist of an optical line terminal (OLT) at service provider central office and optical network units (ONUs) at end users. EPON configuration reduces amount of fiber and equipment at central office. An EPON is point to multipoint communication system providing high speed network connection in which passive optical components (like AWG, power splitter, circulators) are utilized. Data rate of EPON both in upward and downward directions are $2.5 \mathrm{Gbps}$. At ONUs optical signals are converted back into radio signal and used by subscriber and also regeneration take place which is feedback to the input side as downstream signal by the use of TDMA concept. The properties of EPON are given in table-1and EPON architecture shown in figure-1.

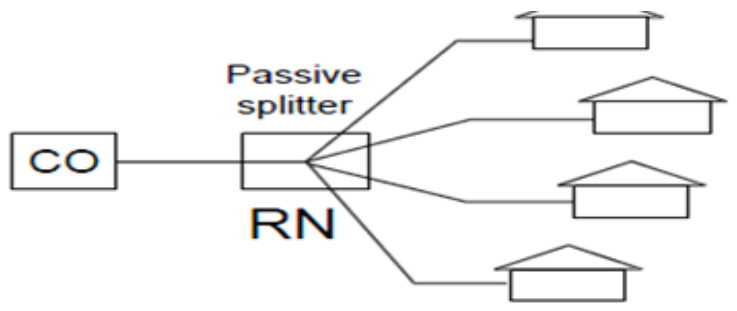

Figure 1: EPON Architecture 
Table1: Properties of EPON

\begin{tabular}{|l|l|}
\hline Quantity Value \\
\hline $\begin{array}{l}\text { Data rate } \\
\text { (upstream) }\end{array}$ & $2.5 \mathrm{Gbps}$ \\
\hline $\begin{array}{l}\text { Data rate } \\
\text { (downstream) }\end{array}$ & $2.5 \mathrm{Gbps}$ \\
\hline $\begin{array}{l}\text { Wavelength } \\
\text { (upstream) }\end{array}$ & $\begin{array}{l}1550 \mathrm{~nm}, 1549.2 \mathrm{~nm}, 1548.2 \mathrm{~nm}, 1547.2 \mathrm{n} \\
\mathrm{m}\end{array}$ \\
\hline $\begin{array}{l}\text { Wavelength } \\
\text { (downstream) }\end{array}$ & $\begin{array}{l}1550 \mathrm{~nm}, 1549.2 \mathrm{~nm}, 1548.2 \mathrm{~nm}, 1547.2 \mathrm{n} \\
\mathrm{m}\end{array}$ \\
\hline PON split & 4 \\
\hline OWC Distance & $50-200 \mathrm{~km}$ \\
\hline
\end{tabular}

\section{SIMULATION DESIGN}

In this section the simulation is done using optisystem-13.The simulation shows that the development of WDM-EPON based OWC transmission using four different wavelength of light. At OLT (optical line terminal) section, PRBS (pseudo random bit sequence) generator have $2.5 \mathrm{Gbps}$ data rate and NRZ pulse generator have $160 \mathrm{GHz}$ operating frequency and Cut-off frequency $1.875 \mathrm{GHz}$ goes to the $\mathrm{MZ}$ modulator where a CW DFD laser array having $5 \mathrm{dBm}$ power used to produce four different wavelengths. WDM is used to multiplex these different wavelengths and send via single channel. After that it modulates the digitized radio Signal with the help of MZ modulator. This Optical Modulated signal gets amplified by EDFA amplifier. Subsequently the amplified signal gets splitted by power splitter of $(1 \times 4)$ size. Circulator is used to pass these signals and it also takes the signal from ONU side and delay is also provided for proper circulation. A bidirectional 4x1 AWG is used after circulator; these signals of different wavelengths are again multiplexed and send with the help of OWC in upward and downward direction. At receiver side these multiplexed signal get DE multiplexed by using AWG of $1 \times 4$ sizes and divided in to four different subscribers at their desired frequency (or wavelength).

These signals are sent via four different single mode fibers at $1-30 \mathrm{~km}$ to its optical network unit to provide FTTH service. By using optical fiber at receiving end to the optical network units; very secured and high bit rate data is received. At ONU; APD photo detectors are used to convert optical signal into radio signal and passed through low pass Bessel filter which passes only information signal and block the unwanted signal. Again signals from this ONUs send back to OLT side by using the same procedure. At input side there are buffer selectors which select only single wavelength for their particular optical line terminals. The Hardware configuration is shown in table-2 and simulation diagram shown in fig 2.

\begin{tabular}{|c|c|}
\hline OWC length & $50-200 \mathrm{~km}$ \\
\hline EDFA & $\begin{array}{l}\text { Gain }=17 \mathrm{db} \\
\mathrm{NF}=6 \mathrm{db}\end{array}$ \\
\hline $\begin{array}{l}\text { PRBS } \\
\text { generator }\end{array}$ & Bit rate $=2.5 \mathrm{Gbps}$ \\
\hline $\begin{array}{l}\mathrm{CW} \quad \text { Laser } \\
\text { array }\end{array}$ & $\begin{array}{l}\mathrm{P}=5 \mathrm{dBm} \\
\text { Wavelength }=1550 \mathrm{~nm} \\
\text { Frequency spacing }=100 \mathrm{GHz} \\
\text { Bandwidth }=10 \mathrm{GHz}\end{array}$ \\
\hline MZ modulator & Extinction ratio $=30 \mathrm{~dB}$ \\
\hline $\begin{array}{l}\text { Photo detector } \\
\text { APD }\end{array}$ & $\begin{array}{l}\text { Responsivity }=1 \mathrm{~A} / \mathrm{W} \\
\text { sample rate }=5 * \text { sample rate }\end{array}$ \\
\hline $\begin{array}{l}\text { NRZ pulse } \\
\text { generator }\end{array}$ & Sample rate $=160 \mathrm{GHz}$ \\
\hline $\begin{array}{l}\text { Low pass } \\
\text { Bessel filter }\end{array}$ & $0.75 *$ bit rate \\
\hline $\begin{array}{l}2 \\
\text { Bidirectional } \\
\text { AWG }\end{array}$ & $\begin{array}{l}\text { One } 4 \times 1 \text { and one } 1 \times 4 \quad B W=10 \mathrm{GHz} \\
\text { frequency1550nm }\end{array}$ \\
\hline WDM & $\begin{array}{l}\chi=1550 \mathrm{~nm} \\
\text { Frequency spacing }=100 \mathrm{GHz} \\
\text { Bandwidth }=10 \mathrm{GHz}\end{array}$ \\
\hline Power splitter & $1 \times 4$ \\
\hline $\begin{array}{lr}\text { Four } & \text { Single } \\
\text { Mode } & \text { Optical } \\
\text { Fiber } & \end{array}$ & $\begin{array}{l}1-30 \mathrm{~km}, \\
\lambda=1550 \mathrm{~nm}, 1549.2 \mathrm{~nm}, 1548.2 \mathrm{~nm}, 1547.2 \mathrm{~nm}\end{array}$ \\
\hline
\end{tabular}

With the help of above hardware configuration parameter the simulation diagram is setup. The property of component used in the system setup is adjusted with the help of above table. As shown in this table the laser light have power $5 \mathrm{dBm}$ and wavelength $1550 \mathrm{~nm}$ which is an infrared light. In this paper array of laser is used so that $100 \mathrm{GHz}$ frequency spacing is provided. Wavelength division multiplexing works on same wavelength and frequency spacing as Laser light is used.

Table 2: Simulation Parameter 


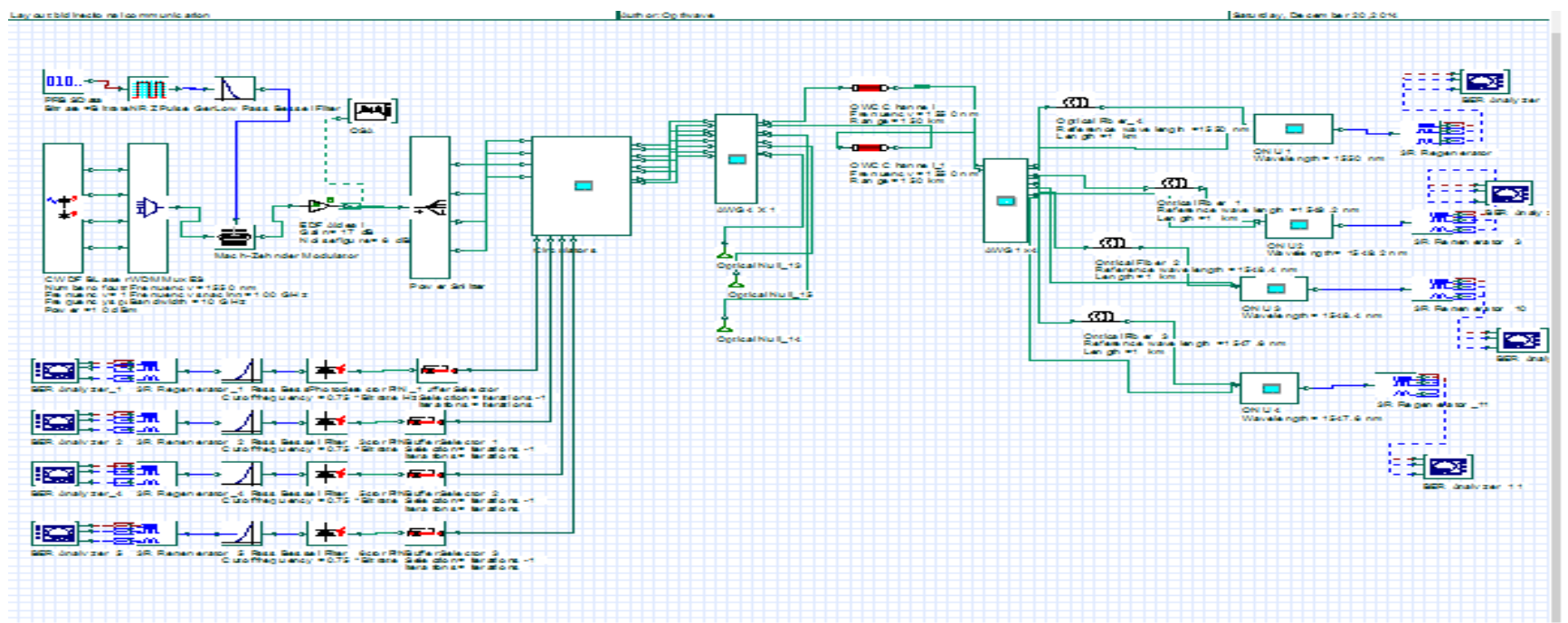

Figure 2: Simulation Design

\section{RESULT AND ANALYSIS}

On the basis of above design, simulation is done and the analysis of system is presented. The same performance is analyzed for upstream and downstream and the results are different for four different ONU's and four OLTs.

\subsection{Eye diagrams while changing the length of OWC}

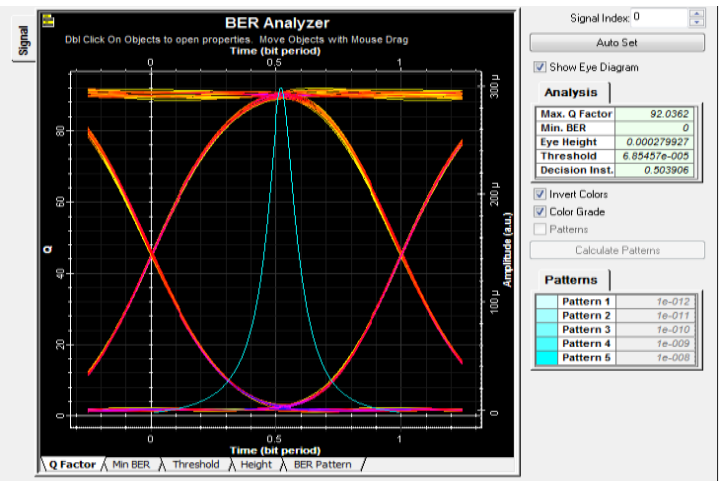

Figure 3: eye diagram at $50 \mathrm{~km}$ of $O W C$ at $\chi=1550 \mathrm{~nm}$

Table 3: Parameters of eye diagram at $50 \mathrm{~km}$ of $\mathrm{OWC}$ $1 \mathrm{~km}$ of optical fiber

\begin{tabular}{|c|c|c|c|}
\hline $\begin{array}{c}\text { Maximum } \\
\text { q-factor }\end{array}$ & $\begin{array}{c}\text { Minimum } \\
\text { BER }\end{array}$ & Eye height & ONU \\
\hline 92.0362 & 0 & 0.000279927 & $\chi_{1=} 1550 \mathrm{~nm}$, \\
\hline 71.336 & 0 & 0.0000278828 & $\chi_{2=} 1549.2 \mathrm{~nm}$ \\
\hline 87.773 & 0 & 0.000281478 & $\chi_{3=} 1548.2 \mathrm{~nm}$ \\
\hline 84.5421 & 0 & 0.000280998 & $\chi_{4=} 1547.2 \mathrm{~nm}$ \\
\hline
\end{tabular}

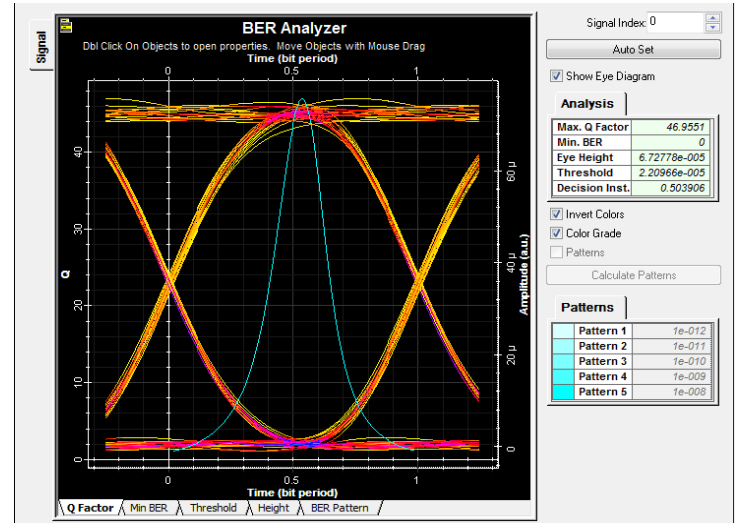

Figure 4: eye diagram at $100 \mathrm{~km}$ of $O W C$ at $\chi=1550 \mathrm{~nm}$

Table 4: Parameters of eye diagram at $100 \mathrm{~km}$ of OWC $1 \mathrm{~km}$ of optical fiber

\begin{tabular}{|c|c|c|l|}
\hline $\begin{array}{c}\text { Maximum } \\
\text { q-factor }\end{array}$ & $\begin{array}{c}\text { Minimum } \\
\text { BER }\end{array}$ & Eye height & ONU \\
\hline 46.09551 & 0 & $6.72778 \mathrm{e}-005$ & $\begin{array}{l}\chi_{1=1550 \mathrm{n}} \\
\mathrm{m},\end{array}$ \\
\hline 38.0383 & $\begin{array}{c}6.5079 \mathrm{e}- \\
317\end{array}$ & $6.75628 \mathrm{e}-005$ & $\begin{array}{l}\chi_{2=1549 .} \\
2 \mathrm{~nm}\end{array}$ \\
\hline 44.5563 & 0 & $6.78946 \mathrm{e}-005$ & $\begin{array}{l}\chi_{3=1548 .} \\
2 \mathrm{~nm}\end{array}$ \\
\hline 48.5159 & 0 & $6.83762 \mathrm{e}-005$ & $\begin{array}{l}\chi_{4=1547 .} \\
2 \mathrm{~nm}\end{array}$ \\
& & & \\
\hline
\end{tabular}




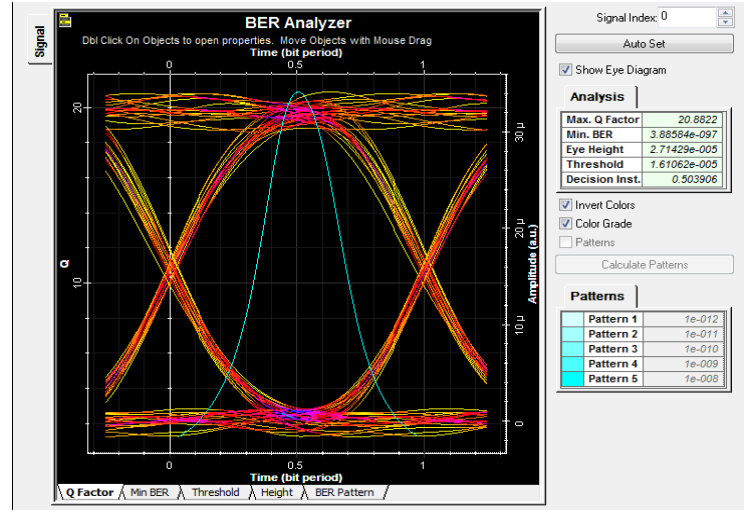

Figure 5: eye diagram at $150 \mathrm{~km}$ of $O W C$ at $\chi=1550 \mathrm{~nm}$

Table 5: Parameters of eye diagram at $150 \mathrm{~km}$ of $\mathrm{OWC}$ with $1 \mathrm{~km}$ of optical fiber

\begin{tabular}{|c|c|c|c|}
\hline $\begin{array}{c}\text { Maximum } \\
\text { q-factor }\end{array}$ & $\begin{array}{c}\text { Minimum } \\
\text { BER }\end{array}$ & Eye height & ONU \\
\hline 20.8822 & $3.8 \mathrm{e}-097$ & $\begin{array}{c}2.7429 \mathrm{e}- \\
005\end{array}$ & $\begin{array}{c}\chi_{1=1550} \\
\mathrm{~nm},\end{array}$ \\
\hline 18.6423 & $\begin{array}{l}6.82359 \mathrm{e}- \\
078\end{array}$ & $\begin{array}{c}2.70078 \mathrm{e}- \\
005\end{array}$ & $\begin{array}{l}\chi_{2=1549} \\
.2 \mathrm{~nm}\end{array}$ \\
\hline 27.7451 & $\begin{array}{c}9.22353 \mathrm{e}- \\
170\end{array}$ & $\begin{array}{c}2.88257 \mathrm{e}- \\
005\end{array}$ & $\begin{array}{l}\chi_{3=} 1548 \\
.2 \mathrm{~nm}\end{array}$ \\
\hline 26.1502 & $\begin{array}{c}4.89572 \mathrm{e}- \\
151\end{array}$ & $\begin{array}{c}2.81567 \mathrm{e}- \\
005\end{array}$ & $\begin{array}{l}\chi_{4=1547} \\
.2 \mathrm{~nm}\end{array}$ \\
\hline
\end{tabular}

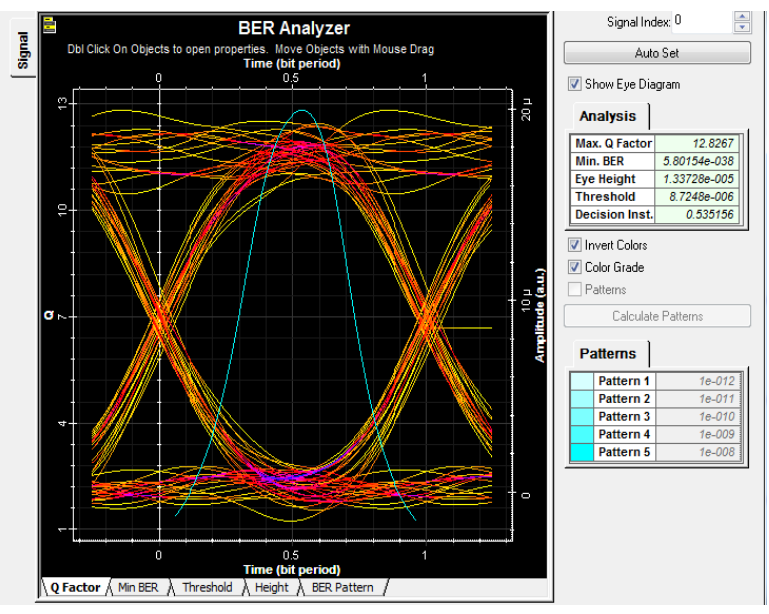

Fig 6:eye diagram at $200 \mathrm{~km}$ of $O W C$ at $\chi=1550 \mathrm{~nm}$
Table 6: parameters of eye diagram at $200 \mathrm{~km}$ of OWC1km of optical fiber

\begin{tabular}{|c|c|c|l|}
\hline $\begin{array}{c}\text { Maximum } \\
\text { Q-factor }\end{array}$ & $\begin{array}{c}\text { Minimum } \\
\text { BER }\end{array}$ & Eye height & ONU \\
\hline 12.8267 & $5.8014 \mathrm{e}-038$ & $\begin{array}{c}1.33728 \mathrm{e}- \\
005\end{array}$ & $\begin{array}{c}\chi_{1=1550} \\
\mathrm{~nm},\end{array}$ \\
\hline 12.8897 & $2.56975 \mathrm{e}-038$ & $\begin{array}{c}1.40232 \mathrm{e}- \\
005\end{array}$ & $\begin{array}{l}\chi_{2=1549 .} \\
2 \mathrm{~nm}\end{array}$ \\
& & $1.4779 \mathrm{e}-005$ & $\begin{array}{l}\chi_{3=} 1548 . \\
2 \mathrm{~nm}\end{array}$ \\
\hline 16.5019 & $1.76392 \mathrm{e}-061$ & & \\
& & $1.45471 \mathrm{e}-$ & $\begin{array}{l}\chi_{4=} 1547 . \\
2 \mathrm{~nm}\end{array}$ \\
\hline 15.1821 & $2.29993 \mathrm{e}-052$ & 005 & \\
& & & \\
& & &
\end{tabular}

From the above analysis it can be seen that as the length of optical wireless channel length increases the q-factor goes on decreasing and min BER goes on increasing. After $200 \mathrm{~km}$ distance the signal quality become poor. The various parameters of eye diagram with variable length of optical fiber is shown in the tables. from tables it is clear that the value of Q-factor and BER is different at different wavelength of optical network unit.

\section{를 Max. Q Factor (Range (km))} Dbl Click On Objects to open properties. Move Objects with Mouse Drag

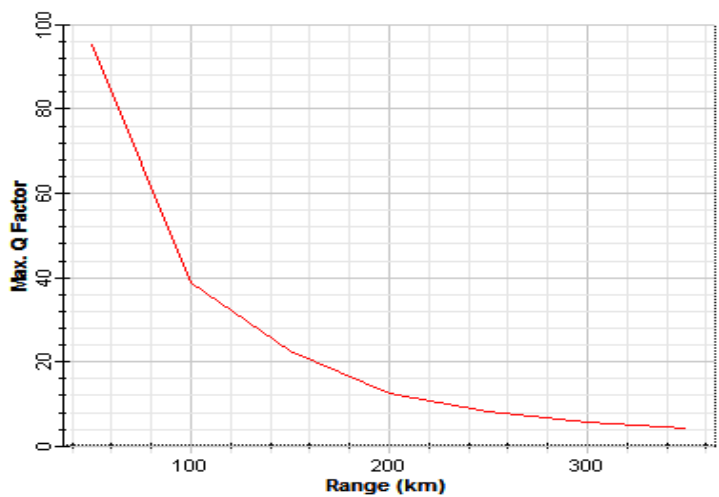

Fig 7: Graph between optical wireless length and Q-factor

The graph between OWC length and Q- factor shows that the Quality of signal decreases as length increases. After 100km distances the q-factor decreases comparatively slowly.

\subsection{Eye diagrams of the received signal while changing the length of Optical Fiber}

The length of single mode optical fiber at receiver side can also change to see the effect on quality of signals. The various parameters of eye diagram at different optical fiber shown below. The Quality factor of signal depends upon the wavelength so that at different wavelength the BER and the Q-factor of the signals are different. The main analysis is based on $1550 \mathrm{~nm}$ wavelength because of minimum interchannel interference is experienced at this wavelength. The tables for Q-factor at different wavelength and different optical fiber length are shown in the tables below. 


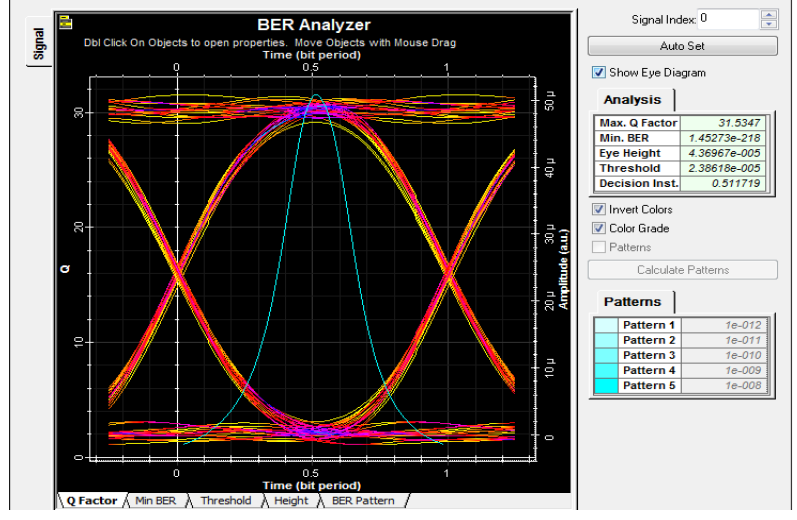

Figure 8:eye diagram at $100 \mathrm{~km}$ of $\mathrm{OWC}$ with $10 \mathrm{~km}$ of optical fiber at $1550 \mathrm{~nm}$

Table 7: parameters of eye diagram at $100 \mathrm{~km}$ of OWC with $10 \mathrm{~km}$ of optical fiber

\begin{tabular}{|c|c|c|c|}
\hline $\begin{array}{c}\text { Maximum } \\
\text { q-factor }\end{array}$ & $\begin{array}{l}\text { Minimum } \\
\text { BER }\end{array}$ & Eye height & $\mathrm{ONU}$ \\
\hline 31.5347 & $1.4527 \mathrm{e}-218$ & $\begin{array}{c}4.36967 \mathrm{e}- \\
005\end{array}$ & $\begin{array}{c}\chi_{1=}=1550 \mathrm{n} \\
\mathrm{m},\end{array}$ \\
\hline 21.2671 & $1.0738 \mathrm{e}-100$ & $\begin{array}{c}4.11917 \mathrm{e}- \\
005\end{array}$ & $\begin{array}{l}\chi_{2=1549 .} \\
2 \mathrm{~nm}\end{array}$ \\
\hline 26.7085 & $\begin{array}{c}1.69517 \mathrm{e}- \\
157\end{array}$ & $\begin{array}{c}4.51881 \mathrm{e}- \\
005\end{array}$ & $\begin{array}{l}\chi_{3=1548 .} \\
2 \mathrm{~nm}\end{array}$ \\
\hline 34.6551 & $1.8627 \mathrm{e}-263$ & $\begin{array}{c}4.3798 \mathrm{e}- \\
005\end{array}$ & $\begin{array}{l}\chi_{4=1547 .} \\
2 \mathrm{~nm}\end{array}$ \\
\hline
\end{tabular}

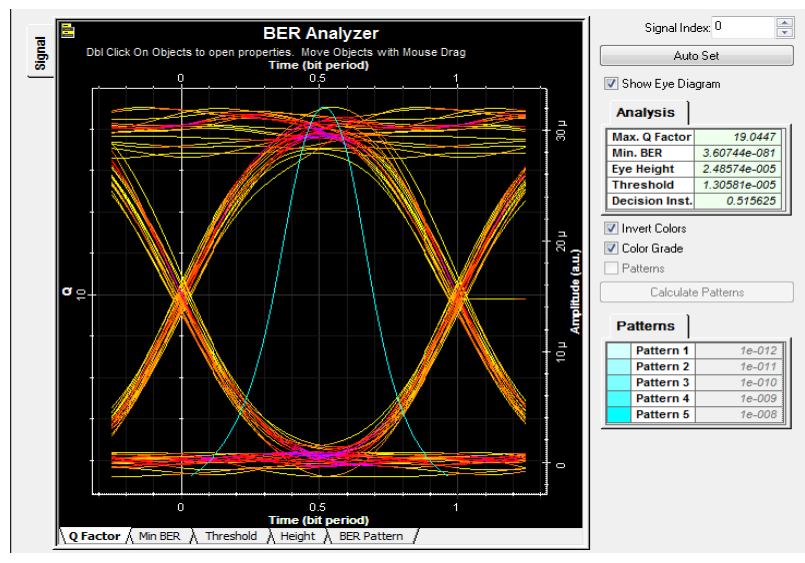

Figure 9: eye diagram at $100 \mathrm{~km}$ of $\mathrm{OWC}$ with $20 \mathrm{~km}$ of optical fiber at $1550 \mathrm{~nm}$
Table 8: Parameters of eye diagram at $100 \mathrm{~km}$ of OWC with $20 \mathrm{~km}$ of optical fiber

\begin{tabular}{|c|l|l|l|}
\hline $\begin{array}{c}\text { Maximum } \\
\text { q-factor }\end{array}$ & Minimum BER & Eye height & ONU \\
\hline 19.0447 & $3.60744 \mathrm{e}-081$ & $2.48574 \mathrm{e}-005$ & $\begin{array}{l}\chi_{1=1550} \\
\mathrm{~nm},\end{array}$ \\
\hline 20.1376 & $1.6997 \mathrm{e}-090$ & $2.61706 \mathrm{e}-005$ & $\begin{array}{l}\chi_{2=1549 .} \\
2 \mathrm{~nm}\end{array}$ \\
\hline 19.2092 & $1.45859 \mathrm{e}-082$ & $2.57056 \mathrm{e}-005$ & $\begin{array}{l}\chi_{3=} 1548 . \\
2 \mathrm{~nm}\end{array}$ \\
\hline 19.9848 & $3.65721 \mathrm{e}-089$ & $2.56834 \mathrm{e}-005$ & $\begin{array}{l}\chi_{4=1547 .} \\
2 \mathrm{~nm}\end{array}$ \\
\hline
\end{tabular}

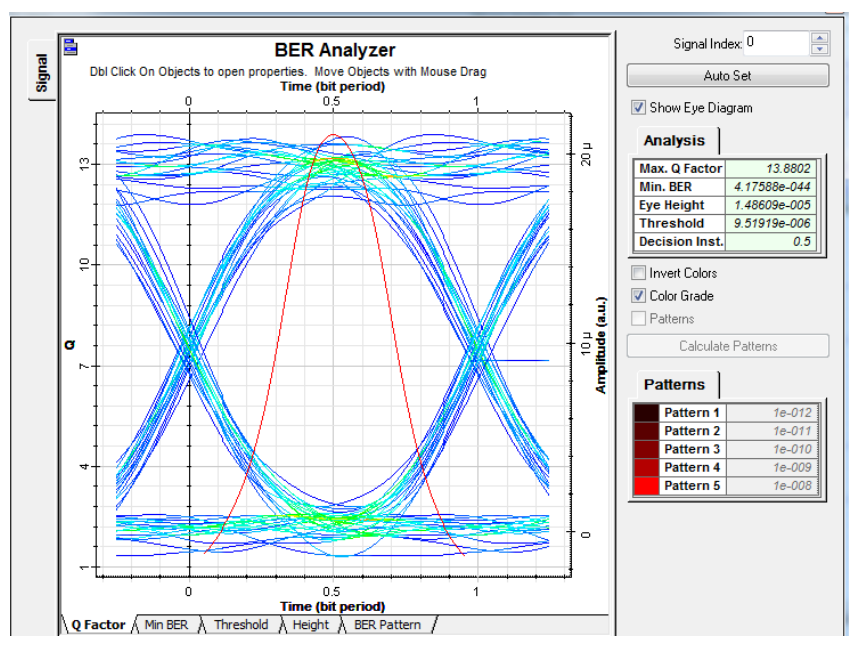

Figure 10: eye diagram at $100 \mathrm{~km}$ of $\mathrm{OWC}$ with $30 \mathrm{~km}$ of optical fiber at $1550 \mathrm{~nm}$

Table 9: parameters of eye diagram at $100 \mathrm{~km}$ of $\mathrm{OWC}$ with $30 \mathrm{~km}$ of optical fiber

\begin{tabular}{|c|c|c|c|}
\hline $\begin{array}{c}\text { Maximum } \\
\text { q-factor }\end{array}$ & $\begin{array}{c}\text { Minimum } \\
\text { BER }\end{array}$ & Eye height & ONU \\
\hline 13.8802 & $4.71588 \mathrm{e}-044$ & $1.48609 \mathrm{e}-005$ & $\chi_{1=1550 \mathrm{~nm},}$ \\
\hline 13.9843 & $9.62509 \mathrm{e}-045$ & $1.52819 \mathrm{e}-005$ & $\chi_{2=1549.2 \mathrm{~nm}}$ \\
\hline 15.8576 & $6.0725 \mathrm{e}-057$ & $1.56536 \mathrm{e}-005$ & $\chi_{3=1548.2 \mathrm{~nm}}$ \\
\hline 14.1856 & $5.49046 \mathrm{e}-046$ & $1.50005 \mathrm{e}-005$ & $\chi_{4=1547.2 \mathrm{~nm}}$ \\
\hline
\end{tabular}




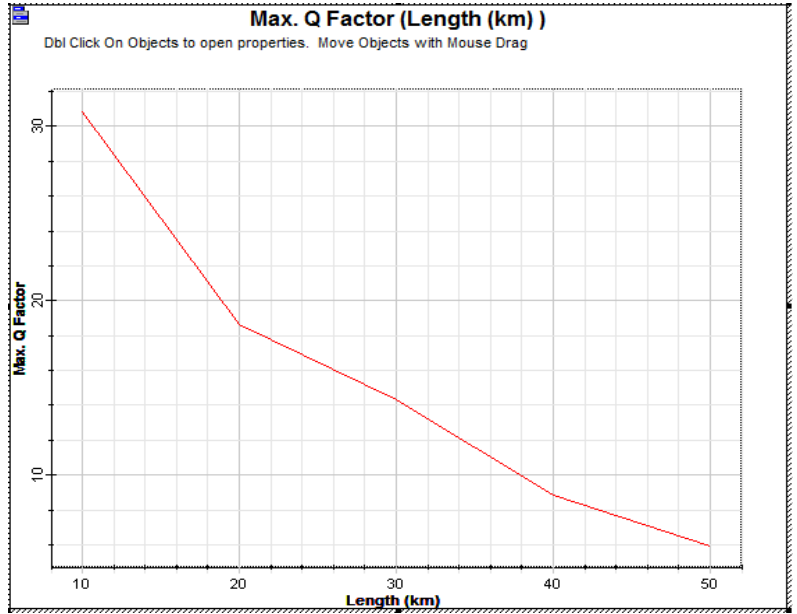

Fig 11: Graph between optical fiber length and Q-factor

The graph between Optical Fiber length and Q -factor shows that,As the length of optical fiber increases the signal quality decreases. The Q-factor of the signal decreases and BER of the signal increases.After every $20 \mathrm{~km}$ length of optical fiber increases the slope of the graph of quality factor is changed.

\section{CONCLUSION AND FUTURE SCOPE}

In this work the performance analysis of bidirectional integrated network of wireless optical channel and optical fiber has been made .The lower BER, higher Q-factor at the output besides good power budget is obtained. Due to very high operating frequency, high data rate, and large bandwidth WDM EPON is very good choice for wireless internet user. As the distance between transmitters and receiver is increases the power loss also increases and Q-factor decreases. The performance of received signal is very good up to $100 \mathrm{~km}$ of OWC length and $20 \mathrm{~km}$ of optical fiber length. Further work may be initiated wherein one can use number of information signal at input side and get number of message signal at receiver side. If anyone want to receive Data signal together with Audio signal and video signal then separate modulation is done with the help of separate laser light for each signal at transmitter end.

\section{ACKNOWLEDGMENTS}

I would like to thank my advisor prof. A.K. Jaiswal H.O.D, SSET, Sam Higginbottom institute of agriculture technology and sciences(deemed-to-be university), Allahabad, for providing guidance and all require facilities and thank to my co advisor Neelesh Agarwal assistant professor, SSET, for their constant co-operation, help, guidance and support during project period.

\section{REFERENCES}

[1] Affida M. Zinet al, (December 2011.)The Characterization of Radio over-Fiber Employed GPON Architecture for Wireless Distribution Network, Member, IEEE International Journal of Machine Learning and Computing, Vol. 1, No. 5

[2] Akhil Gupta et al, (November 2014), Survey of Free Space Optical Communication Network Channel over Optical Fiber Cable Communication .International Journal of Computer Applications (0975 - 8887) Volume 105, No- 10.

[3] A. V. Osadchiv et al, "Converged Delivery of Wi-Max and Wire line Services over an Extended Reach Passive Optical Network", Journal of Optical Fiber Technology, Vol. 16, p. 182-186.

[4] Dr. Ali Mahdi Hammadiet al, (February-2014) Transmission Performance Analysis of Three Different Channels in Optical Communication Systems. International Journal of Scientific \& Engineering Research, Volume 5, Issue 2, 1615 ISSN 2229-5518 IJSER

[5] IshaAggarwal, et al, (2013), Performance Evaluation of Intersatellite Free Space Optical Communication System with Varied Parameters and Transceiver Diversity Advance in Electronic and Electric Engineering. ISSN 2231-1297, Volume3, pp.847-852

[6] Tien-Thang Pham, Integration of Optically Generated Impulse Radio UWB Signals into Baseband WDM-PON

[7] Sandeep(2014) Performance Analysis of Optical WirelessCommunication Link By Multiple Tx/Rx with and Without Amplifier Ajmer, India International Journal of Engineering Research \& Technology (IJERT ISSN: 2278-0181 Vol. 3 Issue 6,

[8] S. Lallukkaet al, (2005) "Link Utilization and Comparison of EPON and GPON Access Network Cost", Proceeding of IEEE Globecome 